\title{
28 Research Suare \\ Root Porosity Contributes to Root Trait Space of Wetland Monocotyledons Independently of Economics Traits.
}

\section{Ziqi Ye}

Laurentian University

Peter Ryser ( $\Delta$ pryser@laurentian.ca )

Laurentian University https://orcid.org/0000-0002-9495-9508

\section{Research Article}

Keywords: Aerenchyma, root longevity, root tissue density, root dry matter content, root economics spectrum, wetland

Posted Date: March 19th, 2021

DOl: https://doi.org/10.21203/rs.3.rs-325043/v1

License: (c) (i) This work is licensed under a Creative Commons Attribution 4.0 International License. Read Full License

Version of Record: A version of this preprint was published at Plant and Soil on November 23rd, 2021. See the published version at https://doi.org/10.1007/s11104-021-05186-3. 


\section{Abstract}

Aims Root aerenchyma, a key adaptive trait to anoxic soils has rarely been integrated into trait-based plant ecology. This study aims to evaluate the relationship between root porosity and root economicsrelated traits among wetland plants, focusing on the effect of aerenchyma on root tissue density, a central trait in plant economics spectrum.

Methods Root porosity, root tissue density with air-space included or excluded (RTD and RTDA), and other root economics-related traits were measured separately for basal and lateral roots of 16 garden-grown Ontario wetland monocots with contrasting root longevities.

Results Interspecific variation in root porosity was unrelated to root economics traits and did not differ between species with long-lived or short-lived roots. Consequently, RTDA better differentiated between species with contrasting root longevities than RTD did, consistently both for basal and lateral roots. Root dry matter content (RDMC) accurately predicted RTDA. A principal component analysis showed that in the root adaptive trait space of wetland plants, the first dimension is defined by economics-related traits, the second dimension by lateral root porosity and the ratio of lateral to basal root length, and the third dimension by basal root porosity.

Conclusions Interspecific variation in the aerenchyma content is independent of root economics: Wetland plants can construct economically conservative or acquisitive roots of any porosity. Consequently, to consistently express root functional relationships among wetland plant species, root tissue density should be expressed with RTDA, i.e., excluding the air space, or with the more easily measured RDMC.

\section{Introduction}

Root economics spectrum (RES), based on morphological and physiological root traits that are associated with resource acquisition and resource conservation, has been suggested to match the aboveground leaf economics spectrum (Mommer and Weemstra 2012; Reich 2014; Roumet et al. 2016). Traits such as specific root length (SRL), root respiration rate, root tissue density (RTD) and root life span have been shown to co-vary across species and biomes, enabling their potential use to form a synthetic spectrum to represent root economics, i.e., patterns of allocation and turnover of carbon and nutrients (Ryser 1996; Roumet et al. 2016; Liu et al. 2016; Han and Zhu 2020). However, it also has been observed that RES is more complex than above-ground trait relationships within the leaf economics spectrum would indicate (Weemstra et al. 2016, 2021; Bergmann et al. 2017, 2020; Freschet et al. 2020a). There are several possible reasons for this complexity. The multiplicity of belowground environmental constraints could result in a multidimensional root economics space (Weemstra et al. 2016), and the commonly used root traits may be inadequate for disentangling different adaptations to the multiple constraints (Freschet et al. 2020a). Thus, the applicability of RES may be ecosystem-dependent, depending on the specific below-ground constraints the plants are subjected to in a given ecosystem (Shipley et al. 2016; Carvajal et 
al. 2018), and, a functional RES may require the use of more specific traits (Poorter and Ryser, 2015; McCormack et al. 2017).

Wetlands are ecosystems that pose such specific constraints on roots. Most importantly, wetland soils are saturated, resulting in a reducing hypoxic or anoxic environment (Mitsch and Gosselink 2015). Wetland plants have adapted to such conditions by developing porous roots that allow transport of oxygen-containing air from the atmosphere down into the oxygen-limited environment, enabling root respiration and affecting the biogeochemistry of the rhizosphere (Armstrong 1980; Lamers et al. 2013; Marzocchi et al. 2019). Such air-conducting tissue, root aerenchyma, can also develop in terrestrial plants, especially in habitats prone to occasional flooding (Visser et al. 2000), but in wetland plants it is constitutive (Laan et al. 1989; Jackson and Colmer 2005). Root porosity, i.e., the fractional air space, varies among different species and habitats, reported values ranging from 5-55\% (Smirnoff and Crawford 1983; Justin and Armstrong 1987; Visser et al. 2000; Pan et al. 2020); root porosity also shows phenotypic plasticity in response to waterlogging (Striker et al. 2007; Ryser et al. 2011). However, despite its importance as an adaptive/functional trait in wetland vegetation and ecosystems, root aerenchyma has rarely been incorporated into the framework of trait-based ecology (Moor et al. 2017; Pan et al. 2019). Studies on the ecophysiology of root aerenchyma generally have not involved economics-related traits, or have only included a small number of species at a time, limiting a general understanding of wetland ecology (Moor et al. 2017; Pan et al. 2019).

The aim of the present study is to elucidate the relationship between the interspecific variations in root porosity and in root economics-related traits among wetland plants. As root porosity is mainly an adaptation to oxygen deficiency, and the economics-related traits are adaptations to nutrient availability and disturbance, the question arises, how these traits interact among wetland plant species (Moor et al. 2017). It has been hypothesized that variation in root porosity might be orthogonal to the expected RES in wetland plants, due to the independent nature of the major selective pressures, i.e., survival under oxygen deficiency and growth under contrasting levels of nutrient supply (Pan et al. 2019). On the other hand, synergy or tradeoffs among the traits could lead to correlations between them. For instance, flooding stress has been shown not only to result in changes in root air space, but also in changes in root diameter and RTD (Visser et al. 2000; Striker et al. 2007; Ryser et al. 2011). Purcell et al. (2019) showed that root porosity correlated with SRL but was independent of dry matter content across a gradient of waterlogging duration.

RTD is considered to be a key root trait in comparative ecology, as it expresses the amount of structural material (dry mass) invested per unit volume of root, thus having consequences both for growth rate and root robustness, and consequently, on life span (Ryser 1996; Birouste et al. 2014). However, variation in the amount of root air space potentially confounds the association of RTD with growth and life span, as gaseous volume does not add to tissue dry mass (Eissenstat et al. 2000; Bouma et al. 2003). The confounding effect would be especially pronounced if root porosity is independent of root economics and if it shows a large interspecific variation. This problem can be solved by measuring the density of the non-gaseous root tissue, i.e., excluding the air space from the volume measurement. Therefore, we 
propose a modified and more specific variable: Root tissue density with air excluded (RTDA), i.e., root dry mass per root volume without its air space. We investigate whether this new variable enables a functional improvement of the wetland RES. In addition, because the measurement of root tissue volume is laborious, we also examine the applicability of root dry matter content (RDMC) as a more easily measurable substitute for RTDA. RDMC has previously been recommended as a decent proxy of RTD among non-wetland plants (Birouste et al. 2014).

This study has two primary objectives: 1) to quantify the confounding effect of root aerenchyma in wetland plants on the relationship between RTD and other root traits, including root life span, and 2) to examine the association of root porosity with economics-related root traits in a regional wetland RES. To capture interspecific variation in root life-span, we chose species based on their contrasting root overwintering habits. Wetland monocots in Northern Ontario with a strongly seasonal climate show two distinct root overwintering habits; they either have roots that all senesce in late autumn, or they have roots that mostly persist to the next growing season (Nieman et al. 2018; Courchesne et al. 2020). This feature allows us to have a binary measure for root life span: short-lived roots with a longevity of one growing season, approximately 5 months at most, or long-lived roots with a longevity of one year, at least. This directly addresses the constraints on RES posed by the trade-off between construction cost and longevity. Besides the interspecific variation, root traits also vary within a given root system (Rose 2017; McCormack et al. 2017). Aerenchyma sharply decreases towards the root apex (Armstrong 1980), implying that basal roots are more porous than lateral roots. Therefore, for a comprehensive view of root trait relationships, we investigated the above-mentioned relations separately for basal and for lateral roots. Furthermore, given the various functional associations of root architecture at the root system level (Freschet et al. 2020b), and its phenotypic response to anoxic soil (Pedersen et al. 2021), we characterized root architecture by the ratio of lateral root length to basal root length.

\section{Materials And Methods}

\section{Species selection}

For this study, sixteen monocotyledonous plant species from Northern Ontario wetlands were selected (Table 1). These species represent two different root overwintering habits. Roots of ten of the species overwinter, and roots of six of the species completely senesce in late autumn (Nieman et al. 2018). Given the differences in root overwintering habit, roots of these species can be considered to be either shortlived ( $<5$ months) or long-lived ( $>1$ year).

\section{Experimental design and growth conditions}

The experiment was conducted outdoors as a pot experiment in Sudbury, Ontario, Canada $\left(46^{\circ} 36^{\prime} \mathrm{N}\right.$, $81^{\circ} 06^{\prime} \mathrm{W}$ ). Study plants originated in local wetlands, grown in mesocosms in a common garden for a few years. Plants in this experiment were vegetatively propagated in early summer 2019 and planted in $2.7 \mathrm{~L}$ pots, $10 \mathrm{~cm}$ in diameter and $34 \mathrm{~cm}$ in height, on sieved wetland soil (Bainbridge Construction, North Bay, ON, Canada), or, in case of four of the species (D. arundinaceum, A. triviale, S. latifolia, T. palustre), in 2.3 
L pots of $15 \mathrm{~cm}$ diameter and $15 \mathrm{~cm}$ height on sieved artificial blend of loam, peat moss and compost (President's Choice ${ }^{\circledR}$ Black Earth Topsoil; Brampton, Loblaws, Canada). The pots were kept in pools filled with groundwater, with the water level at the level of the substrate surface. Iron rods placed in some of the pots did not rust below the substrate surface, indicating hypoxic to anoxic conditions (Owens et al. 2008).

The average growing season in Sudbury lasts 125-145 days, defined as the consecutive number of frostfree days (OMAFRA 2016), between May and October. Temperatures during the growing season were the warmest in July with average daily maxima of $26.8^{\circ} \mathrm{C}$ (Table S1, in Supplementary Information). Between 5 November 2019 and 1 May 2020 the plants were covered with straw and tarps to protect against freezing of the roots. During that time pot temperatures remained mostly between 0.5 and $2^{\circ} \mathrm{C}$, similar to soil temperatures in local wetlands during that time of the year (Courchesne et al. 2020).

\section{Trait measurement}

Seventy-one plants from sixteen species in total were harvested, of which eight species were harvested in September 2019 and eight species in August 2020. For each species, there were three to five replicate plants (Table S2, in Supplementary Information). For each individual plant, ten to twenty root segments consisting of basal root and the connected lateral roots were sampled from a depth of 10 to $20 \mathrm{~cm}$ for the taller pots, and 7 to $13 \mathrm{~cm}$ for the shallower pots. Basal roots and lateral roots were separated using a razor blade while floated in a water-filled dish. To calculate root porosity and root economics traits, the following variables were measured: root length, root fresh mass $\left(m_{\text {fresh }}\right)$, root dry mass $\left(m_{\text {dry }}\right)$, total root volume $\left(V_{\text {root }}\right)$, and the air-excluded root volume ( $\left.V_{\text {air-excluded }}\right)$ (Table 2$)$. All variables were measured separately for basal and lateral roots.

The $m_{\text {fresh }}$ was weighed with a microbalance (MX5; Mettler-Toledo, Greifensee, Switzerland), immediately after removing root surface water by carefully blotting with paper tissues (Visser and Bögemann, 2003). The $m_{\text {dry }}$ was measured after drying in the oven for $48 \mathrm{~h}$ at $70^{\circ} \mathrm{C}$. Root length was determined using the grid-intersection method (Newman 1966; Tennant 1975).

The $V_{\text {root }}$ and $V_{\text {air-excluded }}$ were measured with the pycnometer method (Vernescu and Ryser 2009). This method is a kind of Archimedes' method as described in Birouste et al. (2014), the most direct measurement to $V_{\text {root }}$ based on displacement of water by submersed roots. To be specific, we measured the mass of the pycnometer filled with water $\left(m_{1}\right)$, filled with water and the roots $\left(m_{2}\right)$, and filled with water and roots after a vacuum treatment at about $7 \mathrm{kPa}$ three times for 5 mins in a desiccator $\left(m_{3}\right)$. During the vacuum treatment roots were kept submerged with a weighted mesh, resulting in the vacuumed intercellular space of roots to be filled by water when the air pressure was released. The absence of gas bubbles on the surface of vacuumed roots confirmed the efficiency of the air evacuation. Hence, $V_{\text {root }}$ and $V_{\text {air-excluded }}$ can be calculated with the equations: $V_{\text {root }}=\left(m_{1}-m_{2}+m_{\text {fresh }}\right) / \rho$ and $V_{\text {air- }}$ excluded $=\left(m_{1}-m_{3}+m_{\text {fresh }}\right) / \rho$, respectively, in which $\rho$ is the density of water, $1.00 \mathrm{~g} \mathrm{~cm}^{-3}$ at $25^{\circ} \mathrm{C}$. 
In addition, to test the values of $V_{\text {root }}$ obtained with the pycnometer method, diameter of 100 randomly sampled positions along a root system was measured for eight species using a microscope with an ocular micrometer and the root volume calculated assuming a cylindrical form (Ryser and Lambers, 1995). The strong correlation between the two volume measurements validated the pycnometer method as a reliable way to measure $V_{\text {root }}$ for basal roots $\left(R^{2}=0.78\right)$ and for lateral roots $\left(R^{2}=0.73\right)$.

\section{Calculated traits}

Based on the variables measured, root porosity, specific root length (SRL), root average cross-sectional area (RCSA) and root density-associated traits were calculated (Table 2). Root tissue is physically composed of three phases: solid, liquid and air (Roderick et al. 1999a); root cellular tissue mainly contains the solid and liquid phase but root aerenchyma mainly the air phases. Density of root tissue can be calculated as the ratio of mass and volume, based on different combinations of root phases. Accordingly, traits that reflect root density include the commonly-used root tissue density (RTD; Birouste et al. 2014), root tissue density excluding air (RTDA; new variable), fresh root cellular density as the fresh mass of the cellular tissue volume (i.e. the air-excluded volume; Curran et al. 1996), and root dry matter content (RDMC; Birouste et al. 2014) (Table 2).

We also calculated the lateral to basal root length ratio, as a trait describing root architecture in terms of branching density and elongation of the lower-order roots (Maurel and Nacry 2020). Ratios of different root entities have been used to describe root architecture (Freschet et al. 2020b), either in terms of length, mass, or number of the roots, such as root branching density (Postma et al. 2014) or the mass fraction of specific roots within a root system (Ye et al. 2019).

\section{Statistical analysis}

Most statistical analyses were conducted using average values of each of the 16 species. A two-way ANOVA was used to test the interaction between root order (basal/lateral roots) and root life span (shortlived/long-lived roots) on root traits. The difference between RTD and RTDA was examined with a paired $t$-test separately for basal and lateral roots. Pairwise trait relationships were assessed using Pearson's correlations for basal and lateral roots respectively. The dominant dimensions of the trait space at the root system level were analyzed with a Principal Component Analysis (PCA), including root porosity and key root economics traits of both basal and lateral roots, as well as the lateral to basal root length ratio. From all measurement data of basal and lateral roots, major axis regression were performed using individual plant values for assessing the relationship of RDMC as proxy to RTDA or RTD (Warton et al. 2006; Birouste et al. 2014). Normality and homoscedasticity of data were tested to satisfy the assumptions of parametric analyses. SRL and RCSA were log transformed for Pearson's correlation and PCA. Statistical analyses were performed using R version 4.0.3 (R Development Core Team).

\section{Results}

Trait differences and correlations between basal and lateral roots 
Across the 16 studied wetland species, aerenchyma occupied on average $44 \%$ of the root volume in the basal roots, and $13 \%$ of the lateral roots (Tables 3,4 ). Porosities of basal and lateral roots did not correlate with each other (Table 5). With a CV of $56 \%$ the interspecific variation of root porosity was larger for lateral roots than for basal roots with a CV of 21.5\% (Table S3, in Supplementary Information).

In traits reflecting root density, RTDA, RDMC and fresh root cellular density did not differ between basal and lateral roots, but RTD was $41 \%$ lower in basal roots than in lateral roots (Tables 3 , 4). Unsurprisingly, lateral roots were significantly thinner than basal roots, but basal and lateral root RCSA did not correlate among the species. In contrast, species averages of RTD, RTDA and RDMC correlated between basal and lateral roots (Table 5). Fresh root cellular density varied only little, ranging for all species and roots between 1.01 and $1.15 \mathrm{~g} \mathrm{~cm}^{-3}$ (Table S3, in Supplementary Information).

\section{Trait differences between long-lived and short-lived roots}

Root porosity did not differ between species with contrasting root longevities (Tables 3,4$)$. In contrast, traits reflecting root density (RTD, RTDA, fresh root cellular density and RDMC) were significantly lower and SRL higher in species with short-lived roots compared to species with long-lived roots (Tables 3, 4). RCSA was smaller in species with short-lived roots than in those with long-lived roots, but the difference was only weakly significant (Table 4). The interaction between root order (basal/lateral) and root life span (short-lived/long-lived) was non-significant for all root traits, indicating that trait differences between long-lived roots and short-lived roots were not affected by the root order (Table 4).

Influence of root aerenchyma on measures of root tissue density (RTDA vs. RTD).

Root air content causes RTD to be an underestimation of the production costs per unit root tissue, in basal roots by $44 \%$ and in lateral roots by $13 \%$ (Fig. 1; Table 3); these differences are significant (student $t$-test; $P<0.05)$. As a result, although both RTD and RTDA were on average different for species with the different root life spans, this difference was more consistent for RTDA (Fig. 1). In case of RTD, the threshold separating the species with short-lived and long-lived roots was different for basal and lateral roots, whereas for RTDA the threshold was consistent $\left(0.15 \mathrm{~g} \mathrm{~cm}^{-3}\right)$ (Fig. 1b). In addition, RTDA was more closely correlated with SRL than RTD was, both in basal roots as well as in lateral roots (Table 5).

\section{Trait correlations}

Root porosity did not show statistically significant relationships with root traits related to resource economics, neither in basal nor in lateral roots (Table 5). On the other hand, traits reflecting root density (RTD, RTDA, fresh root cellular density and RDMC) were all positively correlated with each other and negatively with SRL in both root orders. Additionally, RCSA correlated with SRL, both in basal and in lateral roots (Table 5).

Multidimensional 'root adaptive space' of wetland plants 
To compose a trait variation space of root systems, a PCA was conducted using nine traits of basal and lateral roots of the 16 studied wetland species with contrasting root life spans. The included traits were root porosity, root economics-related traits (SRL, RCSA and RTDA) and lateral to basal root length ratio as a root architectural trait. The first dimension ( $46 \%$ of the total variation) was mainly represented by the covariation of RTDA and SRL, in which species with short-lived roots and long-lived roots were clearly clustered to opposite ends along this axis (Fig. 2). The second dimension ( $22 \%$ of the total variation) was dominated by lateral root porosity and the lateral to basal root length ratio, two variables that showed a negative trend with each other (Table 5). In addition, basal root porosity dominates the third dimension ( $12 \%$ of the total variation). The loading value of RCSAs of basal roots and lateral roots were not specific to any dimension (Table S4, in Supplementary Information).

\section{RDMC as the proxy of RTDA}

Among the 140 paired measurements for RTDA and RDMC, there was a strong positive correlation between these two variables, both for basal and lateral roots (Fig. 3). Their numeric values were almost identical with an $R^{2}$ of 0.98 in the linear correlation (Fig. 3), RDMC less than RTDA by $6 \%$ on average (Table 3). The relationship of RDMC with RTD also showed a significant positive correlation, but with a lower correlation coefficient than the relationship with RTDA, especially for basal roots $\left(R^{2}=0.83 ; \mathrm{Fig}\right.$. S1, in Supplementary Information).

\section{Discussion}

Our results demonstrate that interspecific variation in root porosity, an adaptation to oxygen-deficient soils (Justin and Armstrong 1987) is largely independent of root economics traits such as tissue density and root longevity (Ryser 1996; Biroueste et al. 2014). Among wetland monocotyledons with considerable interspecific variation in root porosity and root life span, species with long-lived roots and short-lived roots showed contrasting root tissue densities, but did not differ in their root porosity. The results support the hypothesis by Pan et al. (2019) that suggests a decoupling of root porosity from plant economics in wetland plants and indicates that there might be at least two major underlying constraints on the root construction of wetland plants. This hypothesis is also supported by Purcell et al. (2019) who found that root porosity in ephemeral wetlands varied across a flooding gradient, while tissue dry matter content varied across a gradient of grazing intensity.

RES in wetland plants has rarely been addressed (Moor et al. 2017). Among the wetland plants of the present study, the first dimension of the root trait space was defined by traits related to economics, both of basal and lateral roots, supporting an extrapolation of RES, as described by Roumet et al. (2016), into wetlands. The second dimension was determined by lateral root porosity, accompanied by root architecture expressed as the ratio of lateral to basal root length. A relationship between root porosity and root architecture to match the oxygen-conducting structure with oxygen requirements has been postulated by Pedersen et al. (2021). Hence, this dimension seems to be associated with tolerance to oxygen deficiency. Interestingly, there was no significant correlation between lateral and basal root 
porosities, the latter one being dominant in the third PCA dimension, and varying within a relatively narrow range of high values. Large aerenchyma is required in axial roots to conduct air to lateral roots (Armstrong 1980), but the porosity is constrained by requirements for mechanical strength (Striker et al. 2007).

Root diameter, often considered an important trait for root economics, did not show a clear functional association among the studied wetland plants: Variation in RCSA contributed to several dimensions of the trait space, but in a different manner for basal and lateral roots, and with no crucial role on any of the dimensions. Constraints of root diameter may be order-specific, with independent involvement of the functions of cortical parenchyma, aerenchyma, and stele (Yamauchi et al. 2021), and related to plant size (Ryser 1998) and temperature (Weemstra et al. 2021). Furthermore, the size of cortex is known to be associated with the degree of mycorrhizal infection, which has been suggested to form its own dimension in root economics space (Bergmann et al. 2020). We did not investigate this aspect, but published literature indicates that mycorrhizal infection in submerged wetland plants, especially among species of Cyperaceae is mostly absent or very weak (Peat and Fitter 1993; Miller and Bever 1999).

Eissenstat et al. (2000) and Bouma et al. (2003) point out that aerenchyma formation in wetland plants may confound relationships between tissue density and root life span. The observed lack of correlation between root porosity and root economics shows that this concern is real and that an exclusion of root air space from calculation of root tissue density improves our understanding of the relationships among the economics traits of aerenchymatous roots. Not only does a large interspecific variation in root air space blur relations between the structural costs of root tissue and the species' physiology and ecology, but also, the difference in root porosity between basal and lateral roots creates a difference in RTD between these root orders, whereas RTDA is independent of the order. The latter comparison seems to be more meaningful, given the modular production and senescence of the root systems of herbaceous species, i.e., a basal root produces only one cohort of lateral roots (Sun et al. 2016). Consequently, minimal life-span differences between basal and lateral roots was observed for Ontario wetland monocots (Nieman et al. 2018). Hence, we propose RTDA, tissue density excluding air space, as the functionally more meaningful variable in context of root economics.

Direct determination of root volume by the buoyancy-based method is laborious and time-consuming (Biroueste et al. 2014). Our results confirmed that the more easily measurable fresh mass can accurately approximate root tissue volume (Shipley and Vu 2002; Biroueste et al. 2014), resulting in RDMC being almost identical to RTDA. This is because at least in case of herbaceous tissues the specific weight of fresh plant tissue, varies within a very limited range, only slightly above the specific weight of water $1 \mathrm{~g}$ $\mathrm{cm}^{-3}$ (Roderick et al. 1999b). Moreover, because the measurement of fresh mass is insensitive to tissue air content, the fresh mass is for porous roots a better equivalent to tissue volume than root volume is. Hence, we suggest that RDMC is preferable to RTD to quantify the actual root tissue structural costs. Nonetheless, also fresh mass measurement requires great care, with a delicate balance between removal of surface water, and avoiding tissue dehydration due to evaporation (Freschet et al. 2020b). 
Our data on interspecific variation of root traits in herbaceous wetland species within a region shows a multidimensional trait space with the main adaptation to oxygen-deficient wetland soils, root aerenchyma, being independent of traits related to economics spectrum. As aerenchyma can occupy more than half of the root volume, for a representative assessment of trait-based wetland root economics it is advisable to exclude this air space from calculation of tissue density. This can be done by using RTDA or RDMC, traits that show a close association with root life span, irrespectively of root order. Other root traits, such as porosity and diameter vary independently for basal and lateral roots, indicating that constraints on those traits depend on root order.

\section{Declarations}

\section{Funding}

The research was funded by a Natural Sciences and Engineering Research Council of Canada (NSERC) Discovery Grant (\#RGPIN/6011-2017).

\section{Conflicts of interest/Competing interests}

None

\section{Availability of data and material:}

Data included in Supplementary Information

Authors' contributions: PR conceived of the original idea; ZY carried out the experiment; PR and ZY improved the methodology; $Z Y$ analyzed the data; $Z Y$ and PR wrote the manuscript.

\section{Acknowledgements}

We thank Emile Mainville at Ferme Beaulieu for the support of the experimental garden. Mu Yan-Mei helped with data analysis. The research was funded by a Natural Sciences and Engineering Research Council of Canada (NSERC) Discovery Grant (\#RGPIN/6011-2017).

\section{References}

1. Armstrong W (1980) Aeration in higher plants. In: Woolhouse HW (ed) Adv Bot Res 7:225-332. https://doi.org/10.1016/S0065-2296(08)60089-0

2. Bergmann J, Ryo M, Prati D, Hempel S, Rillig MC (2017) Root traits are more than analogues of leaf traits: the case for diaspore mass. New Phytol 216:1130-1139. https://doi.org/10.1111/nph.14748

3. Bergmann J, Weigelt A, van der Plas F, Laughlin DC, Kuyper TW, Guerrero-Ramirez N, ValverdeBarrentes OJ, Bruelheide H, Freschet GT, Iversen CM, Kattge J, McCormack ML, Meier IC, Rillig MC, Roumet C, Semchenko M, Sweeney CJ, van Ruijven J, York LM, Mommer L (2020) The fungal 
collaboration gradient dominates the root economics space in plants. Sci Adv 6:eaba3756. https://doi.org/10.1126/sciadv.aba3756

4. Birouste M, Zamora-Ledezma E, Bossard C, Pérez-Ramos IM, Roumet C (2014) Measurement of fine root tissue density: a comparison of three methods reveals the potential of root dry matter content. Plant Soil 374:299-313. https://doi.org/10.1007/s11104-013-1874-y

5. Bouma TJ, Hengst K, Koutstaal BP, Van Soelen J (2003) Estimating root lifespan of two grasses at contrasting elevation in a salt marsh by applying vitality staining on roots from in-growth cores. Plant Ecol 165:235-245. https://doi.org/10.1023/A:1022290530303

6. Carvajal DE, Loayza AP, Rios RS, Delpiano CA, Squeo FA (2019) A hyper-arid environment shapes an inverse pattern of the fast-slow plant economics spectrum for above-, but not below-ground resource acquisition strategies. J Ecol 107:1079-1092. https://doi.org/10.1111/1365-2745.13092

7. Courchesne DN, Wilson AZ, Ryser P (2020) Regional distribution patterns of wetland monocots with different root turnover strategies are associated with local variation in soil temperature. New Phytol 226:86-97. https://doi.org/10.1111/nph.16328

8. Curran M, James P, Allaway WG (1996) The measurement of gas spaces in the roots of aquatic plants-Archimedes revisited. Aquat Bot 54:255-261. https://doi.org/10.1016/0304-3770(96)010492

9. Eissenstat DM, Wells CE, Yanai RD, Whitbeck JL (2000) Building roots in a changing environment: implications for root longevity. New Phytol 147:33-42. https://doi.org/10.1046/j.14698137.2000.00686.x

10. Freschet GT, Roumet C, Comas LH, Weemstra M, Bengough AG, Rewald B, Rewald B, Bardgett RD, De Deyn GB, Johnson D, Klimešová J, Lukac M, McCormack ML, Meier IC, Pagès L, Poorter H, Prieto I, Wurzburger N, Zadworny M, Bagniewska-Zadworna A, Blancaflor EB, Brunner L, Gessler A, Hobbie S, Iversen CM, Mommer L, Picon-Cochard C, Postma JA, Rose L, Ryser P, Scherer-Lorenzen M, Soudzilovskaia NA, Sun T, Valverde-Barrantes OJ, Weigelt A, York LM, Stokes A (2020a) Root traits as drivers of plant and ecosystem functioning: current understanding, pitfalls and future research needs. New Phytol. https://doi.org/10.1111/nph.17072

11. Freschet GT, Pagès L, Iversen CM, Comas LH, Rewald B, Roumet $C$, Klimešová J, Zadworny M, Poorter H, Postma JA, Adams TS, Bagniewska-Zadworna A, Blancaflor EB, Brunner I, Cornelissen JHC, Garnier E, Gessler A, Hobbie SE, Meier IC, Mommer L, Picon-Cochard C, Rose L, Ryser P, SchererLorenzen M, Soudzilovskaia NA, Stokes A, Sun T, Valverde-Barrantes OJ, Weemstra1 M, Weigelt A, Wurzburger N, York LM, Batterman SA, de Moraes MG, Janeček S, Lambers H, Salmon V, Tharayil N, McCormack ML (2020b) A starting guide to root ecology: Strengthening ecological concepts and standardizing root classification, sampling, processing and trait measurements. HAL 02918834. https://hal.archives-ouvertes.fr/hal-02918834

12. Han M, Zhu B (2020) Linking root respiration to chemistry and morphology across species. Glob Change Biol 27:190-201. https://doi.org/10.1111/gcb.15391 
13. Jackson MB, Colmer TD (2005) Response and adaptation by plants to flooding stress. Ann Bot 96:501-505. https://doi:10.1093/aob/mci205

14. Justin SHFW, Armstrong W (1987) The anatomical characteristics of roots and plant response to soil flooding. New Phytol 106(3):465-495. https://doi:10.1111/j.1469-8137.1987.tb00126.x

15. Laan P, Berrevoets MJ, Lythe S, Armstrong W, Blom CWPM (1989) Root morphology and aerenchyma formation as indicators of the flood-tolerance of Rumex species. J Ecol 77:693-703. https://doi.org/10.2307/2260979

16. Lamers LP, Govers LL, Janssen IC, Geurts JJ, Van der Welle ME, Van Katwijk MM, Van der Heide T, Roelofs JGM, Smolders AJP (2013) Sulfide as a soil phytotoxin - a review. Front Plant Sci 4:268. https://doi.org/10.3389/fpls.2013.00268

17. Liu B, He J, Zeng F, Lei J, Arndt SK (2016) Life span and structure of ephemeral root modules of different functional groups from a desert system. New Phytol 211:103-112. https://doi.org/10.1111/nph.13880

18. Marzocchi U, Benelli S, Larsen M, Bartoli M, Glud RN (2019) Spatial heterogeneity and short-term oxygen dynamics in the rhizosphere of Vallisneria spiralis: Implications for nutrient cycling. Freshwater Biol 64:532-543. https://doi.org/10.1111/fwb.13240

19. Maurel C, Nacry P (2020) Root architecture and hydraulics converge for acclimation to changing water availability. Nat Plants 6:744-749. https://doi.org/10.1038/s41477-020-0684-5

20. McCormack ML, Guo D, Iversen CM, Chen W, Eissenstat DM, Fernandez CW, Li L, Ma C, Ma Z, Poorter H, Reich PB, Zadworny M, Zanne A (2017) Building a better foundation: Improving root-trait measurements to understand and model plant and ecosystem processes. New Phytol 215:27-37. https://doi.org/10.1111/nph.14459

21. Miller SP, Bever JD (1999) Distribution of arbuscular mycorrhizal fungi in stands of the wetland grass Panicum hemitomon along a wide hydrologic gradient. Oecologia 119:586-592. https://doi.org/10.1007/s004420050823

22. Mitsch WJ, Gosselink J (2015) Wetlands, 5th edn. Wiley, New York

23. Mommer L, Weemstra M (2012) The role of roots in the resource economics spectrum. New Phytol 195:725-727. https://doi.org/10.1111/j.1469-8137.2012.04247.x

24. Moor H, Rydin H, Hylander K, Nilsson MB, Lindborg R, Norberg J (2017) Towards a trait-based ecology of wetland vegetation. J Ecol 105:1623-1635. https://doi.org/10.1111/1365-2745.12734

25. Newman El (1966) A method of estimating the total length of root in a sample. J Appl Ecol 3:139145. https://doi.org/10.2307/2401670

26. Nieman T, Hoogzaad $Y$, Marcotte SJ, Ryser $P$ (2018) Contrasting root overwintering strategies of perennial wetland monocots. Botany 96:653-661. https://doi.org/10.1139/cjb-2018-0065

27. OMAFRA (2016) Climate zones and planting dates for vegetables in Ontario. Queen's Printer for Ontario. [Online.] Available from http://www.omafra.gov.on.ca/english/crops/facts/climzoneveg.htm 
28. Owens PR, Wilding LP, Miller WM, Griffin RW (2008) Using iron metal rods to infer oxygen status in seasonally saturated soils. Catena 73:197-203. https://doi.org/10.1016/j.catena.2007.07.009

29. Pan Y, Cieraad E, van Bodegom PM (2019) Are ecophysiological adaptive traits decoupled from leaf economics traits in wetlands? Funct Ecol 33:1202-1210. https://doi.org/10.1111/1365-2435.13329

30. Pan Y, Cieraad E, Clarkson BR, Colmer TD, Pedersen O, Visser EJ, Voesenek LACJ, van Bodegom PM (2020) Drivers of plant traits that allow survival in wetlands. Funct Ecol 34:956-967. https://doi.org/10.1111/1365-2435.13541

31. Peat HJ, Fitter AH (1993) The distribution of arbuscular mycorrhizas in the British flora. New Phytol 125:845-854. https://doi.org/10.1111/j.1469-8137.1993.tb03933.x

32. Pedersen O, Sauter M, Colmer TD, Nakazono M (2021) Regulation of root adaptive anatomical and morphological traits during low soil oxygen. New Phytol 229:42-49. https://doi.org/10.1111/nph.16375

33. Poorter $H$, Ryser $P$ (2015) The limits to leaf and root plasticity: what is so special about specific root length? New Phytol 206:1188-1190. https://doi.org/10.1111/nph.13438

34. Postma JA, Dathe A, Lynch JP (2014) The optimal lateral root branching density for maize depends on nitrogen and phosphorus availability. Plant Physiol 166:590-602. https://doi.org/10.1104/pp.113.233916

35. Purcell AS, Lee WG, Tanentzap AJ, Laughlin DC (2019) Fine root traits are correlated with flooding duration while aboveground traits are related to grazing in an ephemeral wetland. Wetlands 39:291302. https://doi.org/10.1007/s13157-018-1084-8

36. Reich PB (2014) The world-wide 'fast-slow' plant economics spectrum: A traits manifesto. J Ecol 102:275-301. https:// doi.org/10.1111/1365-2745.12211

37. Roderick ML, Berry SL, Noble IR, Farquhar GD (1999a) A theoretical approach to linking the composition and morphology with the function of leaves. Funct Ecol 13:683-695. https://doi.org/10.1046/j.1365-2435.1999.00368.x

38. Roderick ML, Berry SL, Saunders AR, Noble IR (1999b) On the relationship between the composition, morphology and function of leaves. Funct Ecol 13:696-710. https://doi.org/10.1046/j.13652435.1999.00369.x

39. Rose $L$ (2017) Pitfalls in root trait calculations: How ignoring diameter heterogeneity can lead to overestimation of functional traits. Front Plant Sci 8:898. https://doi.org/10.3389/fpls.2017.00898

40. Roumet C, Birouste M, Picon-Cochard C, Ghestem M, Osman N, Vrignon-Brenas S, Cao KF, Stokes A (2016) Root structure-function relationships in 74 species: evidence of a root economics spectrum related to carbon economy. New Phytol 210:815-826. https://doi.org/10.1111/nph.13828

41. Ryser $P$ (1996) The importance of tissue density for growth and life span of leaves and roots: a comparison of five ecologically contrasting grasses. Funct Ecol 10:717-723. https://doi.org/10.2307/2390506

42. Ryser $P$ (1998) Intra- and interspecific variation in root length, root turnover and the underlying parameters. In: Lambers $\mathrm{H}$, Poorter $\mathrm{H}$, Van Vuuren MI (eds) Inherent variation in plant growth. 
Backhuys Publishers, pp 441-465

43. Ryser P, Gill HK, Byrne CJ (2011) Constraints of root response to waterlogging in Alisma triviale. Plant Soil 343:247-260. https://doi.org/10.1007/s11104-011-0715-0

44. Ryser P, Lambers H (1995) Root and leaf attributes accounting for the performance of fast- and slowgrowing grasses at different nutrient supply. Plant Soil 170:251-265.

https://doi.org/10.1007/BF00010478

45. Shipley B, De Bello F, Cornelissen JHC, Laliberté E, Laughlin DC, Reich PB (2016) Reinforcing loose foundation stones in trait-based plant ecology. Oecologia 180:923-931.

https://doi.org/10.1007/s00442-016-3549-x

46. Shipley B, Vu TT (2002) Dry matter content as a measure of dry matter concentration in plants and their parts. New Phytol 153:359-364. https://doi.org/10.1046/j.0028-646X.2001.00320.x

47. Smirnoff N, Crawford RMM (1983) Variation in the structure and response to flooding of root aerenchyma in some wetland plants. Ann Bot 51:237-249.

https://doi.org/10.1093/oxfordjournals.aob.a086462

48. Striker GG, Insausti P, Grimoldi AA, Vega AS (2007) Trade-off between root porosity and mechanical strength in species with different types of aerenchyma. Plant Cell Environ 30:580-589. https://doi.org/10.1111/j.1365-3040.2007.01639.x

49. Sun K, McCormack ML, Li L, Ma Z, Guo D (2016) Fast-cycling unit of root turnover in perennial herbaceous plants in a cold temperate ecosystem. Sci Rep 6:19698.

https://doi.org/10.1038/srep19698

50. Tennant D (1975) A test of a modified line intersect method of estimating root length. J Ecol 63:9951001. https://doi.org/10.2307/2258617

51. Yamauchi T, Pedersen O, Nakazono M, Tsutsumi N (2021) Key root traits of Poaceae for adaptation to soil water gradients. New Phytol 229:3133-3140. https://doi.org/10.1111/nph.17093

52. Vernescu C, Ryser P (2009) Constraints on leaf structural traits in wetland plants. Am J Bot 96:10681074. https://doi.org/10.3732/ajb.0800312

53. Visser EJ, Bögemann GM (2003) Measurement of porosity in very small samples of plant tissue. Plant Soil 253:81-90. https://doi.org/10.1023/A:1024560322835

54. Visser EJW, Bögemann GM, Van de Steeg HM, Pierik R, Blom CWPM (2000) Flooding tolerance of Carex species in relation to field distribution and aerenchyma formation. New Phytol 148:93-103. https://doi.org/10.1046/j.1469-8137.2000.00742.x

55. Voss E, Reznicek AA (2012) Field manual of Michigan flora. University of Michigan Press

56. Warton DI, Wright IJ, Falster DS, Westoby M (2006) Bivariate line-fitting methods for allometry. Biol Rev 81:259-291. https://doi.org/10.1017/S1464793106007007

57. Weemstra M, Freschet GT, Stokes A, Roumet C (2021) Patterns in intraspecific variation in root traits are species-specific along an elevation gradient. Funct Ecol 35:342-356.

https://doi.org/10.1111/1365-2435.13723

Page $14 / 23$ 
58. Weemstra M, Mommer L, Visser EJ, van Ruijven J, Kuyper TW, Mohren GM, Sterck FJ (2016) Towards a multidimensional root trait framework: a tree root review. New Phytol 211:1159-1169. https://doi.org/10.1111/1365-2745.12734

59. Ye ZQ, Wang JM, Wang WJ, Zhang TH, Li JW (2019) Effects of root phenotypic changes on the deep rooting of Populus euphratica seedlings under drought stresses. PeerJ 7:e6513. https://doi.org/10.7717/peerj.6513

\section{Tables}

Table 1 Species used for this experiment, with their root life span based on their root overwintering habit, and characteristic habitats. 


\begin{tabular}{|c|c|c|c|}
\hline Species & Family & $\begin{array}{l}\text { Root } \\
\text { life } \\
\text { span }^{\mathrm{a}}\end{array}$ & Habitat \\
\hline Alisma triviale Pursh & Alismataceae & $S$ & $\begin{array}{l}\text { Ditches, muddy banks, disturbed } \\
\text { wet ground, wet thickets }\end{array}$ \\
\hline Carex lasiocarpa Ehrh. & Cyperaceae & L & $\begin{array}{l}\text { Sphagnum bog and fen mats, } \\
\text { shallow water }\end{array}$ \\
\hline Carex magellanica Lam. & Cyperaceae & L & $\begin{array}{l}\text { Sphagnum bogs, coniferous } \\
\text { swamps }\end{array}$ \\
\hline Carex oligosperma Michx & Cyperaceae & L & Bogs, fens \\
\hline $\begin{array}{l}\text { Dulichium arundinaceum (L.) } \\
\text { Britton }\end{array}$ & Cyperaceae & $\mathrm{L}$ & Marshy shores, river margins \\
\hline $\begin{array}{l}\text { Eleocharis palustris (L.) Roem. } \\
\text { and Schult. }\end{array}$ & Cyperaceae & L & $\begin{array}{l}\text { Shallow waters along rivers and } \\
\text { lakeshores }\end{array}$ \\
\hline Glyceria canadensis (Michx.) Trin & Poaceae & $\mathrm{L}$ & $\begin{array}{l}\text { Bogs, swamps and wet borders of } \\
\text { lakes, ponds and ditches }\end{array}$ \\
\hline Iris versicolor $\mathrm{L}$. & Iridaceae & $\mathrm{L}$ & $\begin{array}{l}\text { Shores, marshes, river borders, } \\
\text { and wet meadows }\end{array}$ \\
\hline Pontederia cordata L. & Pontederiaceae & $S$ & $\begin{array}{l}\text { Marshy borders of lakes and } \\
\text { streams }\end{array}$ \\
\hline Rhynchospora alba (L.) Vahl & Cyperaceae & $S$ & Bogs, fens \\
\hline Sagittaria latifolia Willd. & Alismataceae & $S$ & Shores of lakes, ponds, streams \\
\hline $\begin{array}{l}\text { Schoenoplectus tabernaemontani } \\
\text { (C. C. Gmel.) Palla }\end{array}$ & Cyperaceae & L & $\begin{array}{l}\text { Shallow water of ponds, lakes, } \\
\text { rivers, ditches, and marshes }\end{array}$ \\
\hline Scirpus cyperinus (L.) Kunth & Cyperaceae & $\mathrm{L}$ & $\begin{array}{l}\text { Wet meadows, ditches, openings } \\
\text { in swamps }\end{array}$ \\
\hline Sparganium emersum Rehm. & Typhaceae & S & $\begin{array}{l}\text { Shores, lakes up to } 6 \mathrm{dm} \text { of water, } \\
\text { stream borders. }\end{array}$ \\
\hline Triglochin maritima L. & Juncaginaceae & L & $\begin{array}{l}\text { Gravelly and marly shores, wet } \\
\text { sandy beaches }\end{array}$ \\
\hline Triglochin palustris $\mathrm{L}$. & Juncaginaceae & S & $\begin{array}{l}\text { Wet sandy or marly shores and } \\
\text { marshy flats }\end{array}$ \\
\hline
\end{tabular}

a Root life span based on the habits of the species' root systems during the winter: L, long-lived overwintering roots; S, short-lived roots senescing each autumn (Nieman et al. 2018). Ecological information based on Voss and Reznicek (2012). 
Table 2 Analysed root traits and their calculations.

\begin{tabular}{|lll|}
\hline Root traits & Abbrev. (unit) & Calculation \\
\hline Root porosity & $\left(\mathrm{mm}^{3} \mathrm{~mm}^{-3}\right)$ & $1-V_{\text {air-excluded }} / V_{\text {root }}$ \\
\hline Root cross-sectional area & RCSA $\left(\mathrm{mm}^{2}\right)$ & $V_{\text {root }} /$ root length \\
\hline Root tissue density & RTD $\left(\mathrm{g} \mathrm{cm}^{-3}\right)$ & $m_{\text {dry }} / V_{\text {root }}$ \\
\hline Root air-excluded tissue density & RTDA $\left(\mathrm{g} \mathrm{cm}^{-3}\right)$ & $m_{\text {dry }} / V_{\text {air-excluded }}$ \\
\hline Fresh root cellular density & $\left(\mathrm{g} \mathrm{cm}^{-3}\right)$ & $m_{\text {fresh }} / V_{\text {air-excluded }}$ \\
\hline Root dry matter content & RDMC $\left(\mathrm{g} \mathrm{g}^{-1}\right)$ & $m_{\text {dry }} / m_{\text {fresh }}$ \\
\hline Specific root length & $\mathrm{SRL}\left(\mathrm{m} \mathrm{g}^{-1}\right)$ & root length/ $m_{\text {dry }}$ \\
\hline Lateral to basal root length ratio & $\left(\mathrm{m} \mathrm{m}^{-1}\right)$ & lateral / basal root length \\
\hline
\end{tabular}

$m_{\text {fresh }}$, the root fresh mass; $m_{\text {dry }}$, the root dry mass; $V_{\text {root }}$ the root volume; $V_{\text {air-excluded }}$, the air-excluded root volume.

Table 3 Mean values of root traits ( \pm SEM) of basal or lateral roots for wetland monocots either with longlived roots ${ }^{a}$ or with short-lived roots ${ }^{b}$.

\begin{tabular}{|c|c|c|c|c|}
\hline Root types & basal roots & & lateral roots & \\
\hline Root life span & long-lived & short-lived & long-lived & short-lived \\
\hline Root porosity $\left(\mathrm{cm}^{3} \mathrm{~cm}^{-3}\right)$ & $0.43 \pm 0.04$ & $0.45 \pm 0.02$ & $0.12 \pm 0.02$ & $0.14 \pm 0.04$ \\
\hline $\mathrm{SRL}\left(\mathrm{m} \mathrm{g}^{-1}\right)$ & $17.4 \pm 3.5$ & $68.9 \pm 17.3$ & $173 \pm 32.6$ & $687 \pm 142$ \\
\hline $\operatorname{RCSA}\left(\mathrm{mm}^{2}\right)$ & $0.65 \pm 0.15$ & $0.44 \pm 0.12$ & $0.039 \pm 0.01$ & $0.021 \pm 0.01$ \\
\hline $\operatorname{RTD}\left(\mathrm{g} \mathrm{cm}^{-3}\right)$ & $0.13 \pm 0.01$ & $0.05 \pm 0.01$ & $0.22 \pm 0.02$ & $0.09 \pm 0.01$ \\
\hline RTDA $\left(\mathrm{g} \mathrm{cm}^{-3}\right)$ & $0.23 \pm 0.02$ & $0.09 \pm 0.01$ & $0.25 \pm 0.02$ & $0.11 \pm 0.01$ \\
\hline Fresh root cellular density $\left(\mathrm{g} \mathrm{cm}^{-3}\right)$ & $1.07 \pm 0.01$ & $1.04 \pm 0.01$ & $1.09 \pm 0.01$ & $1.04 \pm 0.01$ \\
\hline $\operatorname{RDMC}\left(\mathrm{g} \mathrm{g}^{-1}\right)$ & $0.22 \pm 0.02$ & $0.09 \pm 0.01$ & $0.23 \pm 0.02$ & $0.11 \pm 0.01$ \\
\hline Lateral to basal root length ratio $\left(\mathrm{m} \mathrm{m}^{-1}\right)$ & & & $7.0 \pm 2.0$ & $4.5 \pm 1.3$ \\
\hline
\end{tabular}


${ }^{a}$ Ten Species with roots with a life span of more than one year; ${ }^{b}$ six species with roots with a life span of one growing season approximately 5 months at most. SRL, specific root length; RCSA, mean root crosssectional area; RTD, root tissue density; RTDA, root tissue density air-excluded; RDMC, root dry matter content.

Table 4 Two-way ANOVA with the main effects root life span (long-lived, 10 species; short-lived, 6 species) and root order (basal; lateral) on root traits.

\begin{tabular}{|lllllllllll|}
\hline & \multicolumn{2}{l}{ Root life span } & \multicolumn{3}{l}{ Root order } & \multicolumn{3}{cl}{ Interaction } & $R^{2}$ \\
\hline Root traits & $F$ & $P$ & $R^{2}$ & $F$ & $P$ & $R^{2}$ & $F$ & $P$ & $R^{2}$ & total \\
\hline Root porosity & 0.6 & 0.45 & 0 & 107.3 & $* * *$ & 0.79 & 0 & 0.98 & 0 & 0.79 \\
\hline SRL & 35.8 & $* * *$ & 0.21 & 106.7 & $* * *$ & 0.63 & 0 & 0.85 & 0 & 0.84 \\
\hline RCSA & 5.9 & $*$ & 0.02 & 206.5 & $* * *$ & 0.86 & 0.3 & 0.61 & 0 & 0.88 \\
\hline RTD & 40.3 & $* * *$ & 0.45 & 20.1 & $* * *$ & 0.22 & 2 & 0.16 & 0.02 & 0.69 \\
\hline RTDA & 49.4 & $* * *$ & 0.63 & 1 & 0.32 & 0.01 & 0 & 0.92 & 0 & 0.64 \\
\hline $\begin{array}{l}\text { Fresh root cellular } \\
\text { density }\end{array}$ & 15.8 & $* * *$ & 0.35 & 0.4 & 0.56 & 0.01 & 1.1 & 0.31 & 0.02 & 0.38 \\
\hline RDMC & 53.5 & $* * *$ & 0.65 & 1 & 0.33 & 0.01 & 0 & 0.99 & 0 & 0.66 \\
\hline
\end{tabular}

An equivalent for $R^{2}$ was calculated as the sum of the effect in proportion to the total sum of squares. SRL, specific root length; RCSA, root cross-sectional area; RTD, root tissue density (air-included); RTDA, root tissue density air-excluded; RDMC, root dry matter content. *** $P<0.001$, $P<0.05$

Table 5 Pearson correlation coefficients for pairwise trait comparisons of basal roots (lower left) and lateral roots (upper right) across 16 wetland monocot species. The values on the diagonal (in bold and italics) indicate the coefficients for comparisons between basal and lateral roots. 


\begin{tabular}{|c|c|c|c|c|c|c|c|c|}
\hline $\begin{array}{l}\text { Lateral } \\
\text { roots }\end{array}$ & $\begin{array}{l}\text { Root } \\
\text { porosity }\end{array}$ & SRL & RCSA & RTD & RTDA & $\begin{array}{l}\text { Fresh } \\
\text { root } \\
\text { cellular } \\
\text { density }\end{array}$ & RDMC & $\begin{array}{l}\text { Lateral/basal } \\
\text { root length } \\
\text { ratio }\end{array}$ \\
\hline \multicolumn{9}{|l|}{$\begin{array}{l}\text { Basal } \\
\text { roots }\end{array}$} \\
\hline $\begin{array}{l}\text { Root } \\
\text { porosity }\end{array}$ & 0.08 & -0.22 & $0.47^{+}$ & -0.17 & 0.00 & -0.08 & 0.02 & $-0.45^{+}$ \\
\hline SRL & 0.23 & $0.70 * *$ & $-0.88 * *$ & $-0.77 * \star$ & $-0.82 * *$ & $-0.60 *$ & $-0.83^{* *}$ & -0.11 \\
\hline RCSA & 0.02 & $-0.81 \star \star$ & 0.29 & 0.38 & 0.47 & 0.24 & 0.49 & -0.06 \\
\hline RTD & $-0.48^{+}$ & -0.70 * & 0.18 & $0.65^{\star *}$ & $0.98^{\star \star}$ & $0.89 \star \star$ & $0.98^{\star \star}$ & 0.24 \\
\hline RTDA & -0.11 & -0.76 ** & 0.29 & $0.92^{* \star}$ & $0.77^{* *}$ & $0.88^{\star \star *}$ & $0.99 * *$ & 0.16 \\
\hline $\begin{array}{l}\text { Fresh root } \\
\text { cellular } \\
\text { density }\end{array}$ & -0.09 & $-0.79 \star \star$ & 0.49 & $0.79 * *$ & $0.86^{* \star}$ & 0.28 & $0.85^{\star \star}$ & 0.29 \\
\hline RDMC & -0.11 & -0.76 ** & 0.29 & $0.92^{* \star}$ & $0.99 * *$ & $0.84^{\star \star}$ & $0.79 * *$ & 0.14 \\
\hline $\begin{array}{l}\text { Lateral to } \\
\text { basal root }\end{array}$ & -0.14 & -0.35 & 0.29 & 0.27 & 0.28 & 0.22 & 0.29 & \\
\hline $\begin{array}{l}\text { length } \\
\text { ratio }\end{array}$ & & & & & & & & \\
\hline
\end{tabular}

Correlations were significant at: $* *, P<0.01 ; *, P<0.05 ;+, P<0.1$. SRL, specific root length; RCSA, mean root cross-sectional area; RTD, root tissue density; RTDA, root tissue density air-excluded; RDMC, root dry matter content.

Figures 

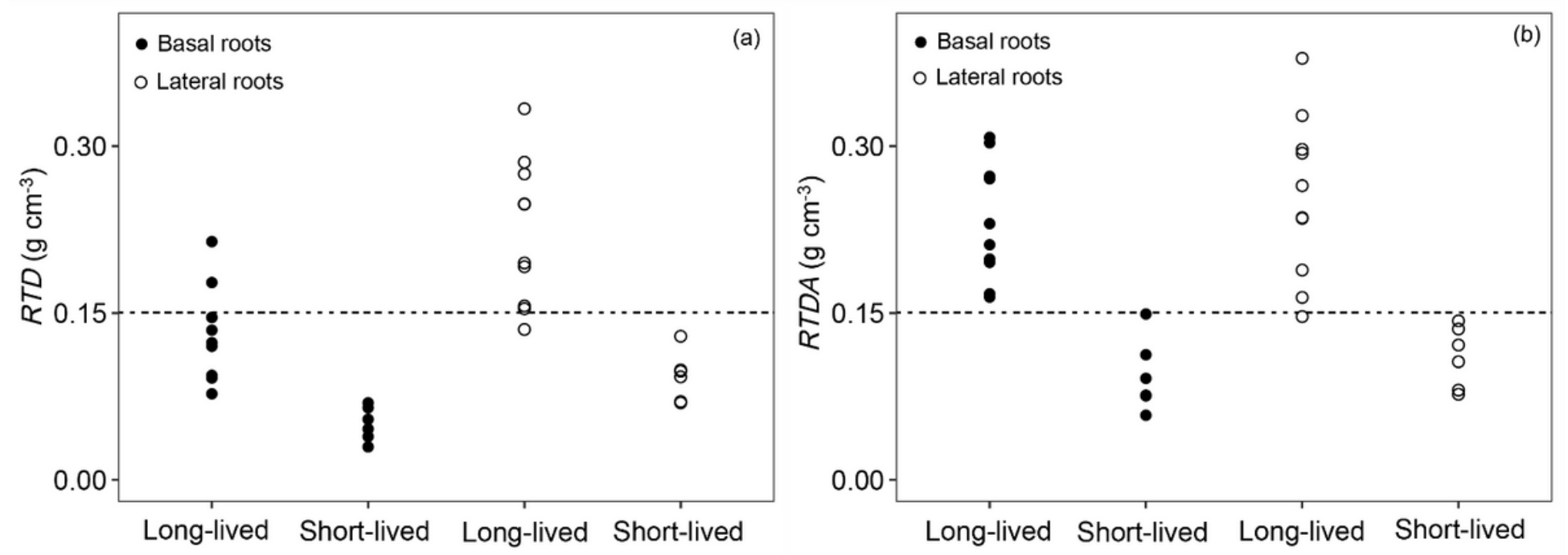

Figure 1

The variation pattern in (a) root tissue density (RTD) and (b) root tissue density air-excluded (RTDA) of basal and lateral roots among 16 plant species grouped by their root life span, i.e., species with long-lived roots (root longevity more than one year; $\mathrm{n}=10$ ) or species with short-lived roots (only one growing season of about 5 months; $n=6$ ). Each dot represents a species mean value with 3-5 replicate plants. 


\section{Basal and lateral roots}

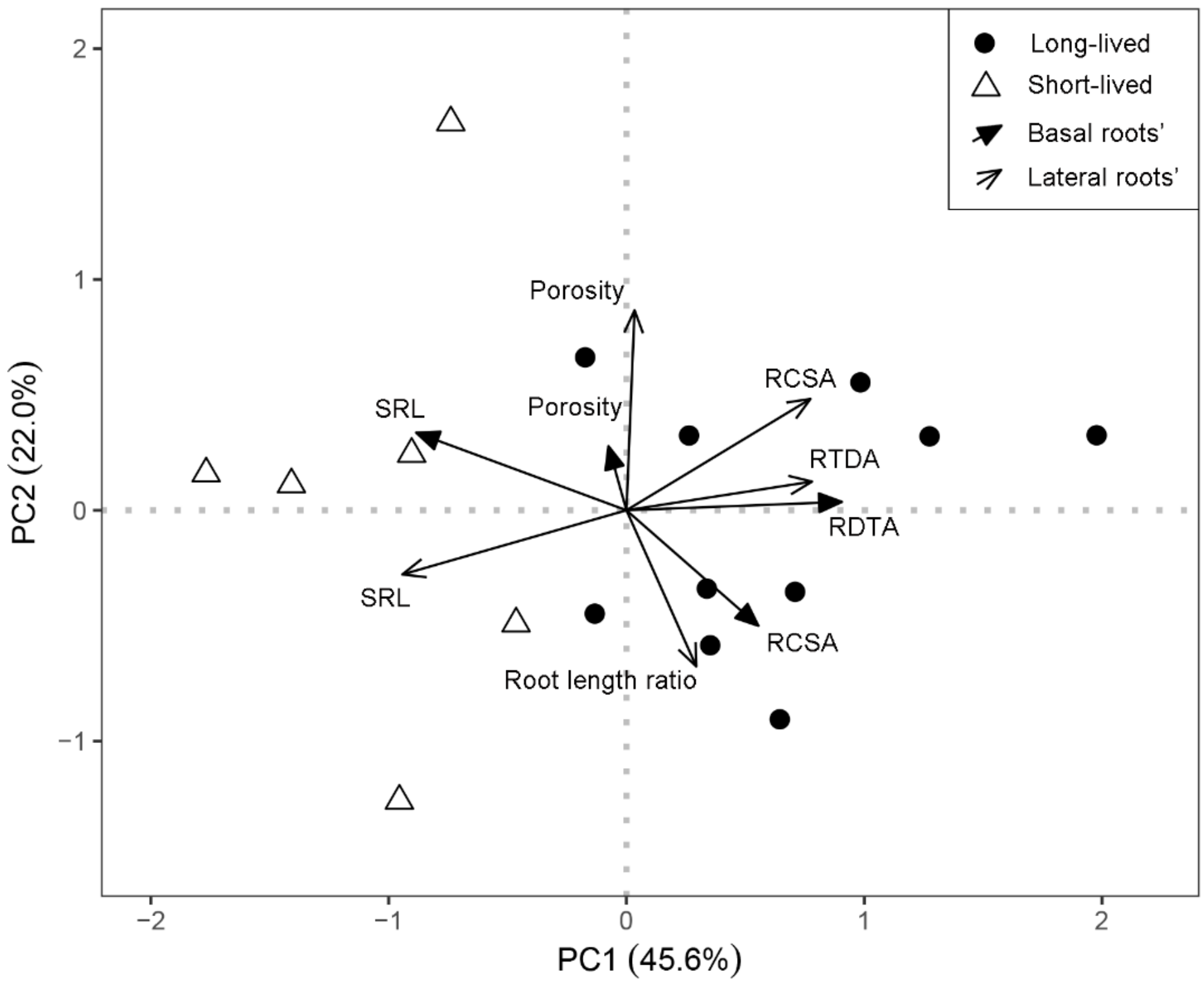

Figure 2

Principal component analysis with nine root traits, including specific root length (SRL), root crosssectional area (RCSA), root tissue density air-excluded (RTDA) and root porosity of basal and lateral roots, and the lateral to basal root length ratio in 16 wetland monocot species. The symbols indicate average values of species either with long-lived (more than one year) or short-lived (one growing season, about 5 months) roots. The coordinates for species used here were scaled down to the half of the original. Loadings of variables see the Table S4 (in Supplementary Information). 


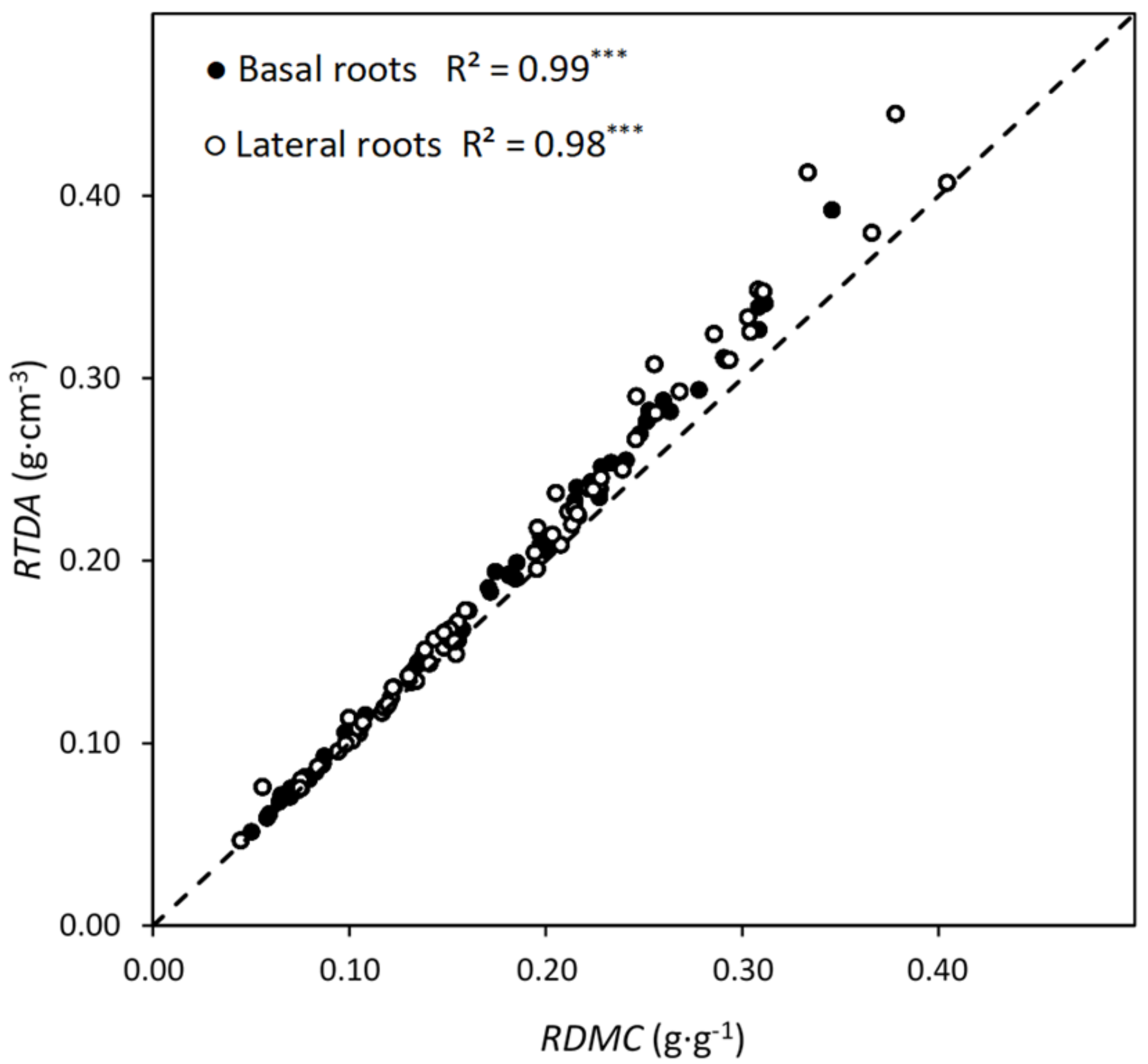

Figure 3

Relationship between root dry matter content (RDMC) and root air-excluded tissue density (RTDA). R2 of the major axis regression are given using original data for basal and lateral roots. For comparative purposes, the 1:1 ratio has been shown by a dotted line. ${ }^{*} *, P<0.001$.

\section{Supplementary Files}

This is a list of supplementary files associated with this preprint. Click to download. 
- SupplementaryinformationYeRyser.docx

Page 23/23 